\title{
PELEH3III
}

DOI https://doi.org/10.32838/2663-6069/2020.4-4/39

Ільӥнська Н. I.

Херсонський державний університет

\section{РЕЦЕНЗІЯ НА МОНОГРАФІЮ КАНДИДАТА ФІЛОЛОГІЧНИХ НАУК, ДОЦЕНТА КАФЕДРИ НІМЕЦЬКОЇ ФІЛОЛОГІЇ І ПЕРЕКЛАДУ ЗАПОРІЗЬКОГО НАЦІОНАЛЬНОГО УНІВЕРСИТЕТУ ТУПАХІНОЇ ОЛЕНИ ВОЛОДИМИРІВНИ «ВІКТОРІАНСЬКИЙ МЕТАНАРАТИВ У ДИСКУРСІ ПОСТСУЧАСНОСТІ: ЛІТЕРАТУРНИЙ ВИМІР ${ }^{1}$}

В умовах постмодерної кризи ідентичності, у постульованій сучасною філософською думкою ситуації «кінця історії», на тлі констатованої Ф. Джеймісоном «історичної глухоти» як маркеру постмодерністського світогляду, що перетворює історію на гранично спрощений, готовий до споживання симулякр, особливої виразності набувають спроби художньої свідомості осягнути себе через співвіднесення 3 історичним Іншим. Феномен «вікторіанського відродження», зокрема його літературний вимір, системно висвітлений у рецензованій монографії, є одним iз показових прикладів такої ідентифікації: чи то через шанобливе наслідування, чи то через канібалістичне поглинання, чи то через іронічне переосмислення розмаїтої літературної спадщини вікторіанської доби.

Зроблена авторкою спроба окреслення генези, характеру, визначальних ознак «вікторіанського відродження», розбудови холістичної візії взаємодії постмодерністської свідомості з вікторіанською історико-культурною спадщиною в літературі межі XX-XXI ст. зумовлює беззаперечну актуальність проведеного дослідження. Його теоретична значущість визначається не лише впорядкуванням термінологічного поля сучасних неовікторіанських студій та обгрунтованим упровадженням низки робочих термінів (як-от «вікторіанський код», «вікторіанський метанаратив»), а й розробленням функціональної класифікації текстів із маркованим вікторіанським референтом, ефективність якої доводиться на широкому текстовому матеріалі.

${ }^{1}$ Тупахіна О. В. Вікторіанський метанаратив у дискурсі постсучасності: літературний вимір : монографія. Запоріжжя : Видавничий дім «Гельветика», 2020. 508 с.
Структура монографії відбиває прозору логіку дослідження. Визначивши зміст і семантичні межі поняття «вікторіанство» в сучасному гуманітарному дискурсі та окресливши основні етапи трансформації його сематичного наповнення 3 моменту виникнення й до початку XXI ст., авторка закономірно переходить до встановлення актуального епістемологічного статусу поняття та виявляе основні модуси, форми й засоби взаємодії художньої свідомості порубіжжя XX-XXI ст. із культурною спадщиною вікторіанської доби.

Особливості художньої рецепції вікторіанського коду постмодерністською свідомістю межі XX-XXI ст. через модуси травми, пам'яті та ностальгії з неминучими трансформаціями під впливом трьох інтерпретативних модальностей - деструкції, деконструкції та реконструкції «постмодерністської чутливості» - здійснюються авторкою на вдало підібраному, тематично й жанрово спорідненому матеріалі 26 романів та оповідей. Поєднані на макрорівні спільним вікторіанським референтом, а на мікрорівні розбиті на окремі групи відповідно до актуалізованої в них певної складової частини вікторіанського метанаративу, у сукупності вони відтворюють досить переконливу літературну мапу «вікторіанського відродження» другої половини XX ст. Окремо варто відзначити широку географію представлених у монографії художніх джерел, що наочно демонструє глобальний масштаб досліджуваного феномену та транснаціональний характер постульованого авторкою «вікторіанського метанаративу».

Авторка, послідовно досліджуючи специфіку рецепції тих чи інших складників вікторіанського 
метанаративу (наративів науки й технологій, літературоцентризму, імперіалізму тощо) такими специфічними жанровими новоутвореннями, як неовікторіанський «природничо-історичний» роман, ретрофутуристичний роман, «біографічний роман про митця», постколоніальний роман тощо, переконливо доводить функціональність розробленої нею матричної моделі, за допомогою якої підносить виявлені окремі факти на вищий рівень наукового й філософського узагальнення.

3 огляду на вищезазначене вважаємо, шо монографія О. В. Тупахіної «Вікторіанський метанаратив у дискурсі постсучасності: літературний вимір» $€$ самостійним і науково значущим дослідженням, яке помітно розширює обрії вітчизняної гуманітаристики. 